\title{
Influence of development of scientometrics on the outlook and functioning of the science system in the world and in individual countries*
}

\author{
Enver Zerem ${ }^{* *}$ \\ Suad Kunosic ${ }^{* * *}$
}

\begin{abstract}
The social significance and quality of scientific research largely depend on the usefulness of research results for the social and scientific community. The lack of funds and the desire to allocate funding to high-quality research projects make the assessment of the quality of research and the valorization of knowledge increasingly important. However, it is very difficult to apply criteria that can objectively assess scientific research, providing precise qualitative and quantitative data on which funding agencies could base their decisions. The product of scientific research is mainly information published in scientific journals. They are the basis for the dissemination of knowledge and the basic criteria for academic and scientific evaluation, fundraising for scientific research and career advancement. In addition to the evaluation of scientific publications, there is a wide range of other activities that reflect the scientific credibility of scientists, such as: number and quality of grants for scientific research projects, leadership in national or international academic societies, membership in editorial boards of reputable journals, doctoral dissertation mentorships and the like.

Although these activities are important and give credibility to the scientist, the relevant scientometric systems cover only publications, neglecting other criteria of scientific importance in evaluation for purpose of academic advancement of a scientist, as well as competitions for grants for financial support of scientific research. The reason for this is the fact that these activities, regardless of their importance, are very heterogeneous, with specific characteristics, and require very diverse parameters for evaluation. Therefore, there are no universal evaluation criteria for these activities and their quality is generally assessed individually, depending on the purpose of the assessment. Regardless of the shortcomings, university ranking systems are important comparative parameters for assessing the quality of scientific and educational value of universities.
\end{abstract}

Key words: internationally recognized criteria, academic community, education, ranking web of world universities

\footnotetext{
${ }^{*}$ This study is financially supported by the Federal Ministry of Education and Science, Federation of Bosnia and Herzegovina, as part of a scientific research project entitled " The impact of the COVID-19 pandemic on scientific production, citations of scientists and ranking of universities in Bosnia and Herzegovina"

** Academy of Sciences and Arts of Bosnia and Herzegovina, Department of Medical Sciences; Cantonal Hospital “Dr. Safet Mujić” Mostar. E-mail: zerem@live.com

${ }^{* *}$ Department of Physics, Faculty of Natural Sciences and Mathematics, University of Tuzla, Bosnia and Herzegovina. E-mail: kunosic@gmail.com
} 


\section{Introduction}

There are only a few processes and events in the history of mankind that have transformed society and contributed to the common good more than science. The knowledge gained through scientific research has saved billions of people from poverty, encouraged industrialization and mass communications of unprecedented proportions, eradicated many diseases and enabled man to leave his mark on the moon. Today, science is a large industry that produces new knowledge, usually aimed to solve certain problems or issues facing humanity. Like any other industry, science uses its tools and resources - scientists, funding and time - to create its products: scientific knowledge, which is presented through publications in the scientific literature.

During the 20th and in the early 21 st century, financing of science was increasingly taken over by the governments and public funds of rich countries and international corporations. The most important public funds and other organizations that finance most scientific research are also the main potential beneficiaries of the results of scientific research, which should be translated into general social progress, and ensure the profit and sustainability of foundations. This is precisely the reason why most of the financial resources are invested in research that should bring benefits to the military industry and competitive advantages in the economy. The realization that investments in biomedical research have been translated into concrete practical progress in several medical disciplines, has achieved strong social support for the investment of public funds in order to support biomedical science.

Large investments in science are mainly focused on basic scientific research, which undoubtedly results in an increase in the knowledge base. However, the research results obtained through basic scientific research are often not comparable with the expected speed of application of these results in practical improvements in industry, social progress and public health. Delayed results in the application of scientific research carry risks of undermining the confidence in science, have negative implications for the financing of scientific research and a relative slowdown in scientific innovation. It is often necessary to conduct additional, so-called, translational research that would enable the transfer of knowledge gained through fundamental research to its practical application.

It should be noted that fundamental (basic) scientific research has a very important essential meaning and social value in the production of new information that enhance the overall human science, and is useful even when 
it does not have a direct tangible outcome in the applied activities. It is also logical to assume that all basic scientific research has a degree of probability of generating tangible results in practice, although such outcomes can be unpredictable and distant both in time and content of application (for example, the theory of general relativity, scientifically proven in 1916, brought a useful outcome for the public good only at the end of the 20th century). ${ }^{1}$

However, despite the essential societal value of the knowledge achieved by fundamental scientific research, it is clear that public agencies and financial funds support scientific research with outcome-oriented goals, including health benefits and disease prevention, promotion and innovation in industry and economy, and increasing profits and return on investment. Precisely because of this, great competition has developed among service providers (universities and scientific institutes) who compete for grants that support scientific research projects. All universities, and often scientific institutes, are institutions that, in addition to their scientific research, have an important role in the education and training of new staff. The educational activity of universities is also financed in a high percentage from public funds and state budgets. $^{2}$

The work of the academic staff a few decades ago was much easier than today. University teachers were obliged to deal with teaching and other forms of student education. Some of them worked on scientific research projects that did not have an imperative of an outcome or a deadline for completion. For example, university teachers in Great Britain had a contract that required them to deal with teaching, religion, and give at least four lectures during the academic year. They also had a general obligation to engage in scientific research work, but without precise criteria for evaluating the research results, nor a deadline for completing the research. Yet, even in such a relaxed atmosphere, with no pressure on scientists and no major investment in infrastructure and research, the hard work of innovators and the inquisitive minds of scientists have made some epochal discoveries (e.g. Sir Godfrey Hounsfeld, the discovery of computed tomography). ${ }^{3}$ With the arrival of Margaret Thatcher as prime minister, new rules for university teachers were introduced in the academic community of Great Britain, and later in the whole of Europe: fiveyear renewable contracts according to precisely agreed goals and conditions for contract renewal, according to criteria based on scientometric parameters.

\footnotetext{
${ }^{1}$ Ashby, 2003:1-42; Bowen \&Casadevall, 2015:11335-40.

${ }^{2}$ Horton, 1998:892.

${ }^{3}$ Hounsfield, 1973:1016-22
} 
The new contracts for university staff introduced by Prime Minister Margaret Thatcher were not greeted with enthusiasm in the academic community, not only by unambitious university teachers but even by eminent scientists and inventors of epochal discoveries. For example, Max Perutz, co-discoverer of the haemoglobin structure (with John Kendrew), vigorously argued that discoveries like theirs could not have been made under the new principles of treating science with short-term contracts, because a particular invention requires almost two decades of development after the initial discovery before it enters routine application in practice. ${ }^{4}$ Numerous scientists have argued that negative pressures on scientific institutions and scientists, and time constraints on research, can contribute to the relative slowdown of scientific innovation and lead to the neglect of the educational / teaching component in university work. Unlike the definition of output-input based efficiency, evaluating previous research results of research by scientists and scientific institutions who are applying for grants is much more complicated.

However, in absence of studying and monitoring the outcomes, it is not possible to find out whether society's investment in research pays off in relation to inputs, and the efficiency and effectiveness of scientific institutions, as well as the practical significance of scientific innovations compared to research investments, cannot be assessed. Monitoring scientific inputs, results, and outcomes can be used to assess the productivity of research institutions and can be useful in assessing future reforms and policy changes. To be applicable. the system of quality indicators should be as simple and rational as possible in terms of providing the necessary information for adequate assessment of the quality of research. Depending on the context of use, it is possible to distinguish different aspects of quality. The quality of research indicates the usefulness of research results for the scientific community within one or more scientific disciplines. Social quality, which is gaining in importance, indicates the usefulness of research results for a wider group: government, economy and industry, institutions of culture and civil society. In real practice, the quality of scientific research is determined by independent experts - peer-review - on the basis of international scientometric parameters. Depending on the purpose, the peer-review can be supported and supplemented by other quality indicators that cannot be expressed by scientometric parameters (received grants, participation in editorial boards of scientific journals, position in the academic community, mentoring in scientific projects and doctorates, etc.).

\footnotetext{
${ }^{4}$ Kendrew\&Perutz, 1948:375-98.
} 


\section{Quality Assessment Criteria for s Scientific Research}

The social significance and quality of scientific research largely depend on the usefulness of research results for the social and scientific community. The lack of funds and the desire to allocate funding to high-quality research projects make the assessment of the quality of research and the valorization of knowledge increasingly important. However, it is very difficult to apply scientific criteria that can objectively assess scientific research, providing precise qualitative and quantitative data on which funding agencies could base their decisions.

The key question, which has always remained elusive in science and education, is on the basis of which criteria this quality is measured, and how to ensure the fulfilment of standards so that all provide adequate quality of output competencies. Since scientific research work can be measured and evaluated far more exactly through innovations, patents, and publications, in relation to educative and other activities represented in higher education, these parameters often appear as predetermining measurements in evaluating the quality of higher education. ${ }^{5}$

The quality of scientific research and the overall scientific production evaluated through innovations, patents and publications are mostly influenced by: GDP, percentage of allocations from GDP for scientific research, international criteria for valorization of scientific research, conditionality of academic progress and scientific valorization and international scientific communications.

The product of scientific research is mainly information published in scientific journals and they are the basis for the dissemination of knowledge, as well as the basic criteria for academic and scientific evaluation, raising of funds for scientific research and career advancement. It is true that, in addition to the evaluation of scientific publications, there is a wide range of other scientific activities that also reflect the scientific credibility of scientists, such as: number and quality of grants for research projects, leadership in national or international academic societies, membership in editorial boards of reputable journals, service in national committees for expert examination of state-sponsored scientific research projects, mentorships in doctoral dissertations, the number of expert and thematic articles in the so-called lay press and the like. ${ }^{6}$

\footnotetext{
${ }^{5}$ Dixon, 2009: 847-50; Zerem, 2017: 107-9; Zerem \& Kunosić, 2018: 133-4

${ }^{6}$ Miles, 1991:643-5; Zerem, 2013:128.
} 
Although these activities are important and give certain weight to the scientific credibility of a scientist, the relevant metric scientific systems cover only publications and omit other criteria of scientific importance, which would make sense to use in assessing the academic advancement of a scientist and in competitions for grants for financial support of scientific research. The reason for this is the fact that these activities, regardless of importance, are very heterogeneous, as each of them has specific characteristics and requires different parameters for evaluation. Therefore, there are no universal evaluation criteria for these parameters of scientific importance, and their value is generally estimated individually, depending on the purpose of the assessment. $^{7}$

\section{Ranking of Universities and Attitude Towards Ranking in Countries in our Region}

The competition to take a prestigious place on the world ranking list of top universities is increasingly heating up and taking on the characteristics of a battle for status and various kinds of domination of the most developed countries in the world. Significant financial resources are being invested in the formation of various international university ranking lists. Relevant university ranking lists consider various parameters, but for most universities (with the partial exception of the first 100) the number of publications and the impact that these publications achieve through citation are of the greatest importance in ranking.

The most prestigious ranking lists of universities in the world publish their results once or twice a year. In academic communities, as well as in the media of the countries of the region, these results are given great importance and they are followed very actively, sometimes fervently, and sometimes even too emotionally in relation to the rationality expected from members of academia. Some universities from the countries of the region - primarily the Universities of Ljubljana, Belgrade and Zagreb - have made significant progress in recent years on international rankings. The academic communities in these countries are constantly evaluating and finding opportunities for the advancement of their universities on the ranking lists, and the media analyse and compare the results of their universities with the results of other universities in the world and especially in the region.

${ }^{7}$ Marušić\&Marušić, 1999:1713-14; Zerem, 2014:248-51; Zerem, 2018:147-8. 
The situation in Bosnia and Herzegovina is, however, paradoxical. Contrary to the long-standing, in our public already established axiom opinion that we are the best, all our universities are either not ranked on international lists at all or are ranked significantly below universities of similar rank in the region. As far as the public knows, no founder (political mentor) of our universities has asked that improving the position on international rankings be a condition in assessing the success of the university they are the founder of, nor did any university set that as a goal at the beginning of a year. In such an atmosphere at the university and in society, how can one find enough strength to strive for true (globally recognized) values, and strength that could improve our universities on the world quality rankings?

\section{Why Rank Universities?}

In an effort to make the traditional education system more open and flexible, there is a noticeable step towards its decentralization, not only territorial, but also more functional, as well as strengthening the autonomy in education and training. In a decentralized education system, governance is implemented through goals and outcomes that promote equality and reproduce a common value base.

In that process, the position of higher education is especially complicated, because scientific research is an inevitable part of it, and without that part, higher education remains uninventive and unable to justify its purpose. Since scientific research, through innovations, patents and publications, can be measured and evaluated much more accurately in relation to educational and other activities represented in higher education, these parameters often appear as predetermining metrics in evaluating the quality of higher education. Opponents of this way of evaluating universities note that in this way teaching in fact is not evaluated, but rather only scientific work, so this way of ranking universities does not reflect all parameters of university quality, especially those that reflect the modernity and quality of programs, teaching and professors. However, most agree that these irregularities apply only to low-ranking universities where a relatively small number of publications can cause statistical "artifacts", while the publication of a large number of significant scientific publications, which is a characteristic of high-ranking universities, requires adequate quality in other segments of activity as well. ${ }^{9}$

\footnotetext{
${ }^{8}$ Zerem, 2013:128; Zerem, 2014:248-51.

${ }^{9}$ Petković, 2013; Zerem, 2014:248-51.
} 
Global rankings are often subject to criticism and outrage, especially from those who are dissatisfied with the position of their universities in ranking and evaluation at various levels, but the fact is that, so far, no possible alternatives to this trend have been offered. It is therefore logical to conclude that, despite constant changes and evolution in the design of academic quality rankings, as well as other shortcomings, analyses of ranking systems show that they are becoming part of the reality and work of thousands of universities worldwide. Comparable information on higher education institutions, their teaching and research programs, should make it easier for students and researchers to choose where and what to study and where to work. Better information would also help policy-makers at the institutional, national and European levels to develop a future strategy for higher education. The current, largely one-dimensional rankings do not meet these purposes because they tend to focus on specific aspects of research and on entire institutions rather than on individual programs and disciplines. This approach requires new forms of management and programming of scientific research and educational work. The main goal in this direction is to establish an efficient and flexible system of accreditation of providers / organizers of educational services and certification of acquired knowledge and skills. ${ }^{10}$

\section{Existing University Ranking Systems}

The ranking of universities should include criteria such as: education, research, quality of teaching staff, international cooperation and funding (finances) that universities achieve through their work. Relevant criteria are those that can be expressed quantitatively, such as: number of enrolled students, percentage of graduates, the ratio of teachers to students, number of doctoral dissertations, awards for both teachers and students and "alumni" students, citations, number of papers published on SCI or SSCI lists, number of patents, number of international journals published by the university or faculty, number of foreign authors in those journals, website and available web services, university libraries, equipment of laboratory and classroom space, etc. Important metrics of university quality are also revenues from tuition fees, funding from state funds, funding from EU funds, etc. One of the very important criteria is international cooperation where an analysis would be performed on the number of foreign students studying at the university as well as the number of students who went to study at other universities (student mobility). Also,

\footnotetext{
${ }^{10}$ Petković, 2015.
} 
for the overall evaluation of the work of a university, the number of visiting professors at the university is important, as well as the number of professors elected at that university who have been elected as visiting professors at other universities.

Although the number of university ranking systems is increasing every year, there are four most significant and most representative lists, which rank universities around the world using different parameters and scoring methods. The most important ranking lists of universities are: the Shanghai Ranking, the Times Higher Education Supplement - THES, WEBOMETRICS ranking and SCImago ranking. ${ }^{11}$

\section{The Shanghai Ranking}

The Academic Ranking of World Universities (ARWU) was first published in June 2003. Shanghai Jiao Tong University School of Education, China, updates this list every year. ARWU uses six objective indicators to rank universities, including the number of alumni and professors who have won Nobel Prizes and medals in specific fields, the number of highly cited researchers in journals who are cited in the Thomson Scientific database (now the "Clarivate Analytics Journal List"), the number of articles published in the journals "Nature" and "Science", the number of articles indexed in the Science Citation Index - Expanded and in the Social Sciences Citation Index, and the per capita effect in relation to the size of the institution. Each year, ARWU ranks more than 1,000 universities and publishes the top 500 online.

\section{The Times Higher Education Supplement - THES}

The Times Higher Education Supplement (THES) has ranked universities since 2004. THES ranking is based on four criteria that are considered to represent the quality of university work, namely: high-quality research, highquality teaching, high employment rate of graduates and a good "international image". The problem with this way of ranking is some of the criteria that are objectively difficult to measure, such as the criterion of high-quality teaching.

\footnotetext{
${ }^{11}$ Hall,1998:1230; Klaic, 1997:88-98.
} 


\section{WEBOMETRICS ranking}

Ranking Web of World Universities is an initiative of the Cybermetrics Lab a research group of the Center for Humanities and Social Sciences (CCHS), part of the National Research Council - CSIC in Spain. The Cybermetrics Laboratory ranks universities based on quantitative analysis of content on the Internet and the web, especially those related to teaching processes and academic communication. With these rankings, the webometrics team wants to further motivate researchers around the world to publish more and better scientific content on the web, and to make them available to colleagues and others interested people around the world. The ranking of world universities "Webometrics" was officially launched in 2004 and is updated every 6 months (data are collected in January and July and are published one month later).

\section{SCImago Ranking}

SCImago is a research group that deals with IT analysis in various fields. It consists of the Institute for Politics and Public Affairs of the National Research Council of Spain (CSIC), the SCImago Institute and several universities (University of Granada, Carlos III University of Madrid, University of Extremadura, University of Alcala de Hanares and University of Porto). SCImago Institutional Ranking - SIR is a global ranking list that ranks institutions from the RDI sphere (universities, colleges, institutes, research centres, hospitals, business companies, etc.) that have at least 100 indexed publications annually. In the SIR ranking tables, higher education organizations and RDI institutions are ranked based on the total number of publications based on searches in the SCOPUS database. ${ }^{12}$

\section{Ranking of Universities on Bosnia and Herzegovina}

Universities and faculties in Bosnia and Herzegovina are increasingly more educational and less scientific institutions, and symbolize the 'mix' of secondary and higher education, without becoming either one in the original sense of the word. Before the last war 1992-1995, there were 4 public universities in BiH (Sarajevo, Tuzla, Mostar and Banja Luka). In that period, the faculties and universities of Bosnia and Herzegovina were mostly created from already existing scientific institutions (usually institutes), which had been engaged in

\footnotetext{
${ }^{12}$ Brennan-Krohn, 2011.
} 
scientific research work for years before that. The faculties were founded in a logical way by which the institutes, as already respectable scientific institutions, acquired an educational role, and in that way grew into faculties for that specific scientific field.

What happened to our academic community during and after the last war? If the war could have been an excuse for certain shortcomings in the initial post-war years, it can hardly be an excuse for us 25 years after the war. Why, in the meantime, have we not been able to restore the position and importance to higher education that it deserves? The shortest answer to this question would be: We have failed to introduce criteria, which would turn the uncontrolled-growing quantity of higher education institutions into quality. ${ }^{13}$

Thus, during 2002, there were 43 higher education institutions in the education system of Bosnia and Herzegovina in the rank of universities / colleges or independent faculties (10 public universities / faculties and 33 in private ownership), and in 2012 there were 25 universities with 177 faculties in $\mathrm{BiH}$, 10 academies and 4 religious study faculties. Since then, the number of higher education institutions in our country has been constantly growing. However, this uncontrolled growth of the number of higher education institutions is not even remotely accompanied by an increase in scientific production, which would be logical to expect from so many universities and faculties. Scientific research work, and scientific publications as its most relevant evaluation confirmation, are the basic driving energy of higher education. Without that driving energy, our higher education has become a severely ill patient whose "blood turns to water" (or where science is replaced by politics), reduced to a mere educational component conducted by incompetent protagonists.

If we are to apply the ranking lists described in this article (Shanghai Ranking, The Times Higher Education Supplement - THES, SCImago ranking, Webometrics list) to our universities, it should be noted that our universities are ranked only on the Webometrics list. The other three lists directly rank only the top one thousand universities and none of our universities are represented on them. Webometrics list ranks virtually all registered universities (over 30,000 universities and colleges) twice a year (January and July), based on educational and scientific criteria. These criteria are continuously evolving and are changing to a lesser extent, but, in essence, the components (educational and scientific) which are the basis of Webometrics ranking remain.

${ }^{13}$ Zerem, 2013:128; Zerem,2014:248-51 
Figure 1 shows the ranking of the most successful universities in $\mathrm{BiH}$ from 2014 to 2021, with cross-sections for both annual rankings (January and July). The University of Sarajevo is the only one of our universities that is positioned on the Webometrics list among the 2000 best universities (between 1500 and 2000 places) in the world, except in July 2015 and 2018, when it was positioned below the 2000th position. The fact is that the University of Sarajevo is our best ranked university, but it is also a fact that it is ranked lower compared to all public universities in Slovenia, Croatia (except the University of Osijek) and Serbia. Also, it is noticeable on the chart that it stagnated in the observed period, not showing a tendency of progress that would put it in a position to be ranked on other ranking lists. Such a modest position of our largest university, with by far the largest resources and budget, has had a negative impact on the development of science, our other universities and higher education in our country.

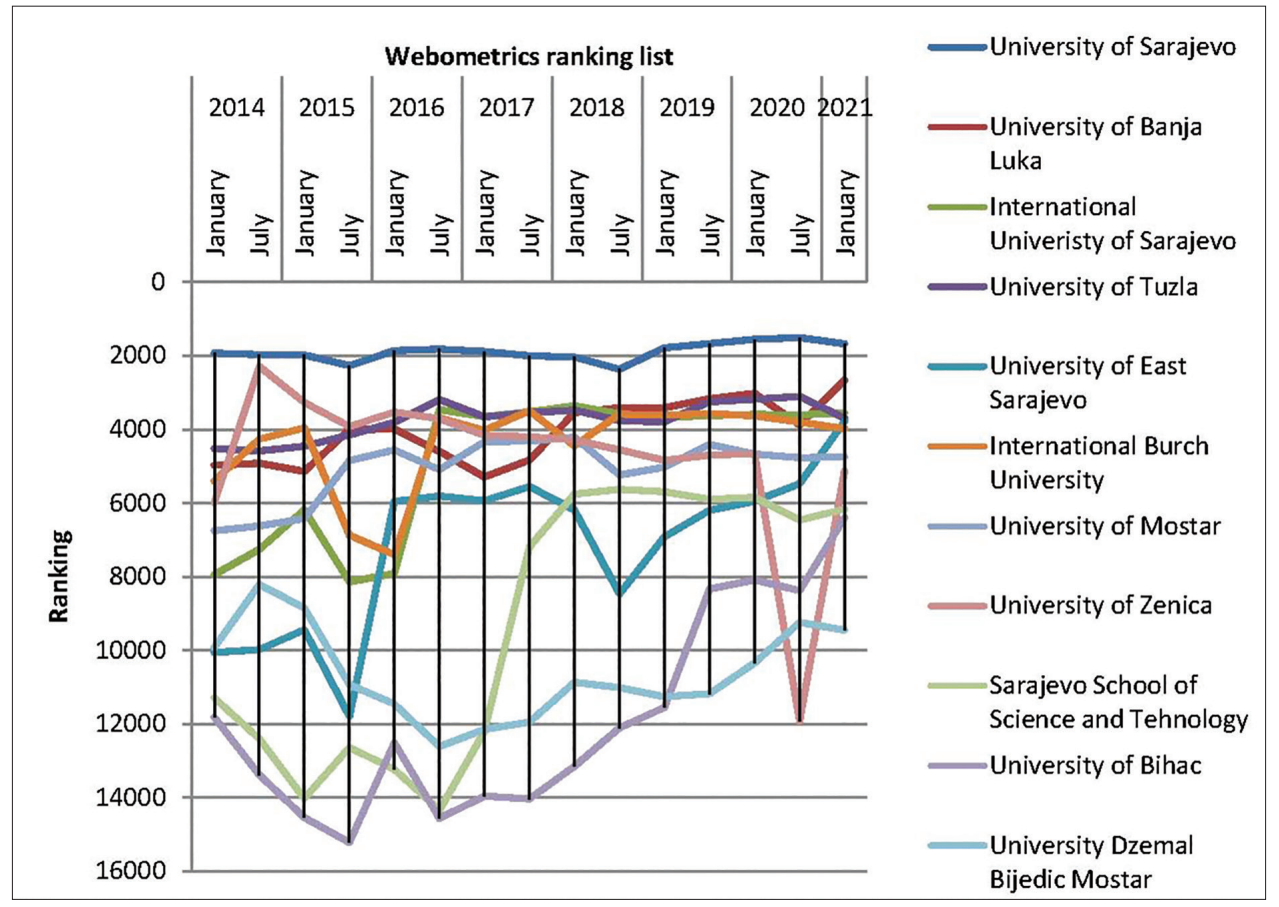

Figure 1. Overview of the most successful universities in BiH according to the Webometrics ranking list for the period 2014-2021.

The University of Banja Luka is the second-ranked university in our country on the most recent ranking list (January 2021), and along with Sarajevo, our only university ranked among the 3000 most successful universities. In the 
analysed period (since 2014), the University of Banja Luka shows a gradual growth and from 4977th place it reached 2658th place, and in the ranking of $\mathrm{BiH}$ universities it rose from fourth to second place. ${ }^{14}$ The University of Tuzla was the second-ranked university in $\mathrm{BiH}$ until the end of 2016, after which it was positioned between 3500 and 4000th place on the overall Webometrics list and moved from second to fourth place among $\mathrm{BiH}$ universities. Other public universities in $\mathrm{BiH}$ were ranked below the 4000th place on the Webometrics list in the analysed period, with occasional short-term upward trends (Zenica in 2014), which were more the result of adjusting to the current criteria of the Webometrics list than of continuous objective quality. The graph shows that the largest nominal progress in the analysed period was achieved by the University of East Sarajevo (rose by 6270 positions) and the University of Bihać (rose by 5412 positions). Although their success, focusing only on numbers, is impressive, if we observe the positions of these universities against the trend of changing criteria on the Webometrics list shown in Table 1, which are not in favour of small universities, we should remain reserved regarding further progress of these universities on the Webometrics list.

Among the private universities in $\mathrm{BiH}$, the International University of Sarajevo is the best positioned one, and is also the third best positioned university in $\mathrm{BiH}$. This university presents the fact that staff selection and collaboration with a more powerful umbrella university is a good recipe for solid success in the competition of our universities. International Burch University operated in a similar manner, with similar results, until 2016. After 2016, the International Burch University had certain staffing problems which is reflected in their drop on the ranking list.

In the ranking for January 2021, the ranking methodology used by Webometrics was changed so that only 3 criteria were used for the ranking of universities (Table 1). Figures 2, 3 and 4 show the ranking of our most successful universities according to each of the three criteria separately. These figures show some facts that more objectively present the quality of work of our universities. The most obvious fact is that, according to the "Impact Rank" criterion, two private universities (European University of Brcko and European University Kallos) that have the same owner are ranked first and third in the competition of our universities. At the same time, according to the "Openness Rank" and "Excellence Rank" criteria, neither of these two universities is ranked in the top 10 in the comparison of $\mathrm{BiH}$ universities.

\footnotetext{
${ }^{14}$ Kunosić, S., Čeke, D., Zerem, E, 2019; Čeke\&Kunosić, 2021.
} 
These facts certainly require a more detailed analysis, but even without the analysis it can be said that there is a great interest of some private universities for faster progress on the ranking lists which is not in line with their realistic quality, as well as that there is insufficient interest of some other, primarily public universities for the same.

Table 1. Webometrics university ranking methodology (January edition, 2021)

\begin{tabular}{lllll}
\hline INDICATORS & MEANING & METHODOLOGY & SOURCE & WEIGHT \\
\hline PRESENCE & & This indicator has been discontinued & \\
\hline VISIBILITY & $\begin{array}{l}\text { Web contents } \\
\text { Impact }\end{array}$ & $\begin{array}{l}\text { Number of external networks (subnets) linking to } \\
\text { the institution's webpages (normalized and then the } \\
\text { maximum value is chosen) }\end{array}$ & $\begin{array}{l}\text { Ahrefs } \\
\text { Majestic }\end{array}$ & $\mathbf{5 0 \%}$ \\
\hline $\begin{array}{l}\text { TRANSPARENCY } \\
\text { (or OPENNESS) }\end{array}$ & $\begin{array}{l}\text { Top cited } \\
\text { researchers }\end{array}$ & $\begin{array}{l}\text { Number of citations from Top 210 authors (excl. } \\
\text { top 20 outliers) }\end{array}$ & $\begin{array}{l}\text { Google Scholar } \\
\text { Profiles }\end{array}$ & $\mathbf{1 0 \%}$ \\
\hline $\begin{array}{l}\text { EXCELLENCE } \\
\text { (or SCHOLAR) }\end{array}$ & $\begin{array}{l}\text { Top cited } \\
\text { papers }\end{array}$ & $\begin{array}{l}\text { Number of papers amongst the top 10\% most } \\
\text { cited in each one of the all 27 disciplines of the full } \\
\text { database } \\
\text { Data for the five year period: 2015-2019 }\end{array}$ & Scimago & $\mathbf{4 0 \%}$ \\
\hline
\end{tabular}

With their new methodology Webometrics has harmonized the weight percentages between educational and scientific criteria. Apart from that, Webometrics is continuously raising the impact of scientific criteria which affect the ranking of universities in the whole world. The change in criteria has also significantly influenced the positions of some universities in $\mathrm{BiH}$, as evident from Figures 2, 3. and 4.

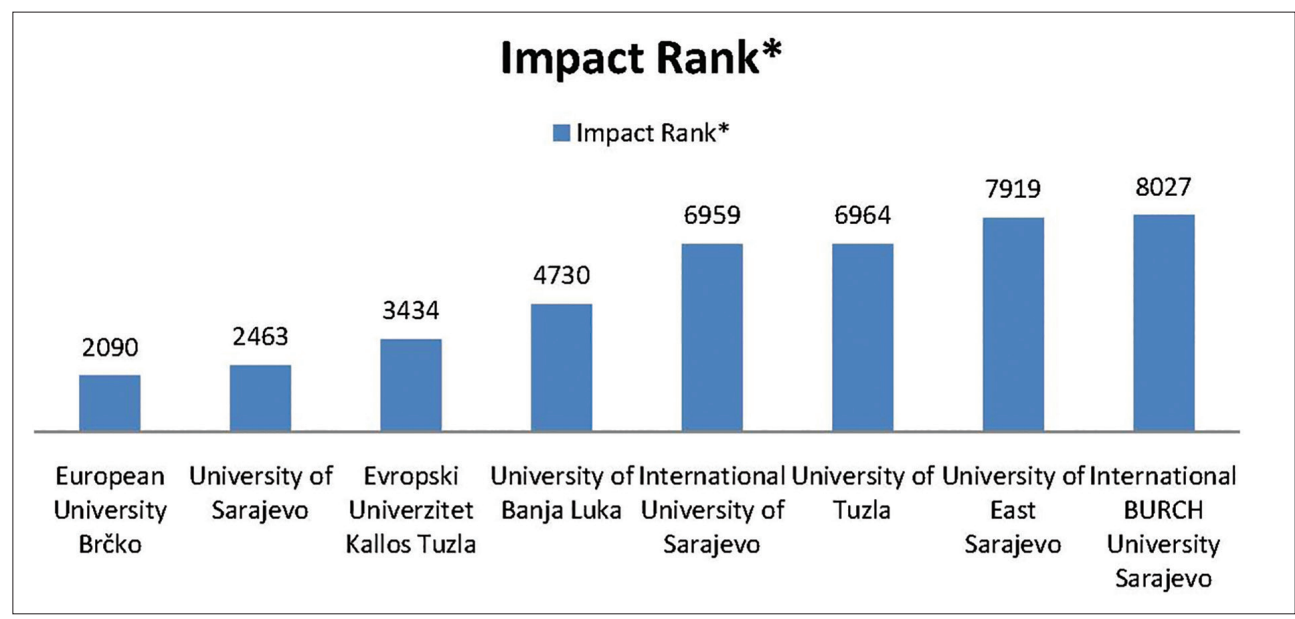

Figure 2. Overview of the most successful universities in BiH according to the "Impact Rank" criterion for January 2021. 
According to the "Impact Rank" (Figure 2) best position is the European University Brčko, and among the 8 top ranked in this category are 4 private universities. It is noticeable that public universities in $\mathrm{BiH}$ have a lot of room for improvement according to this ranking criterion, which objectively offers the quickest and easiest progress on the ranking lists.

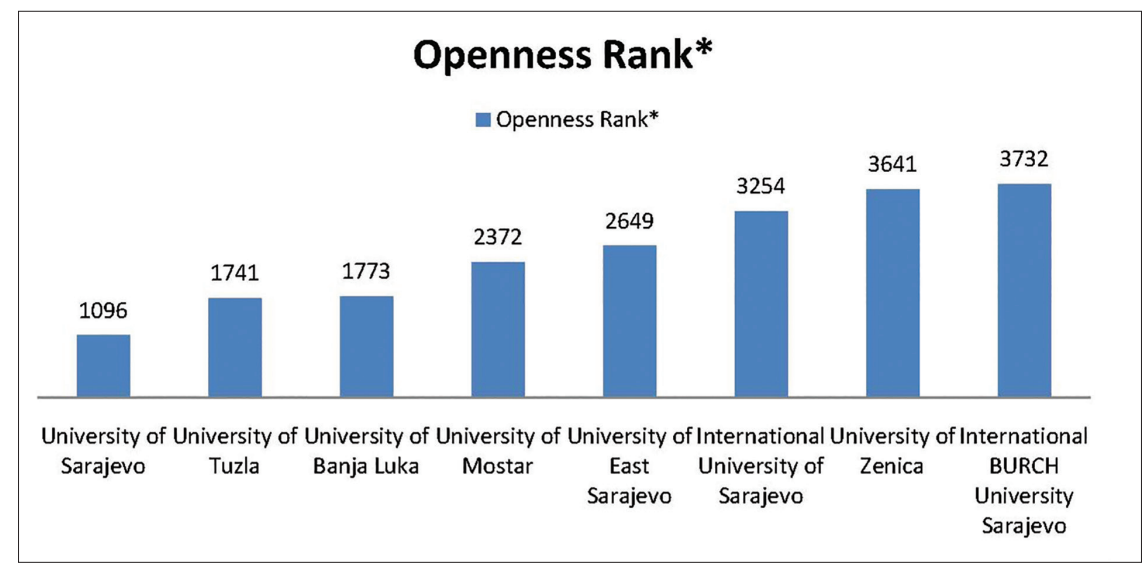

Figure 3. Overview of the most successful universities in BiH according to the "Openness Rank" criterion for January 2021.

In contrast to the previous "Impact Rank" criterion, the "Openness Rank" criterion which is based on the number of citations from the google scholar and represented in Figure 3, there is visible advantage of public universities, with universities that have the most employed scientists leading the group.

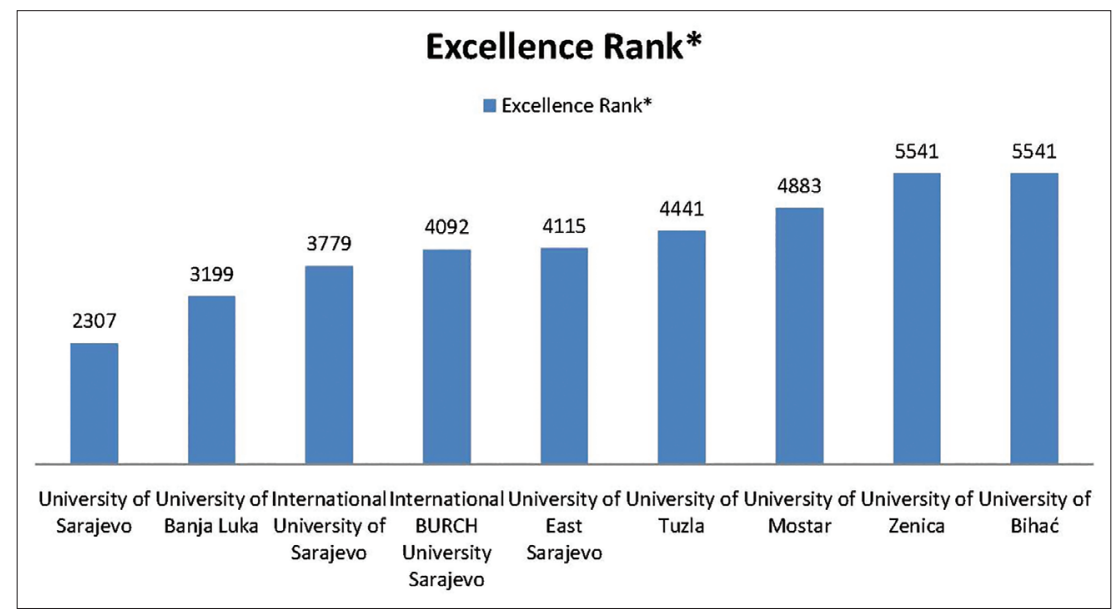

Figure 4. Overview of the most successful universities in BiH according to the "Excellence Rank" for January 2021. 
The most important scientific criterion, "Excellence Rank", which represents 40 percent of the total score on the Webometrics ranking, shows that the positions of the top three universities in $\mathrm{BiH}$ according to this criterion are identical to the top three positions of $\mathrm{BiH}$ universities on the overall Webometrics list (Figures 1 and 4).

In the SJR: Scimago report for the period 1996-2019 (Figure 5), Bosnia and Herzegovina ranks 95th in the world according to the number of published scientific articles, but with a lower citation rate than Macedonia, which has a smaller number of published articles. The best positioned regional countries on the list are Croatia, which is on the 50th position, Slovenia (52nd) and Serbia (53rd). Slovenia has the largest number of citations and the largest $\mathrm{H}$ index in relation to all other countries that emerged after the breakup of Yugoslavia.

\begin{tabular}{|r|l|r|r|r|r|r|r|}
\hline Rank & lountry & Doc & Citable doc & Citations & Self-citat & Citat per doc & H index \\
\hline 50 & Croatia & 113256 & 107688 & 1146885 & 197804 & 10,13 & 282 \\
\hline 52 & llovenia & 101460 & 96022 & 1490029 & 224168 & 14,69 & 310 \\
\hline 53 & Serbia & 101388 & 95763 & 989159 & 184758 & 9,76 & 247 \\
\hline 95 & Bosnia and Herzegovina & 13884 & 12961 & 94225 & 9735 & 6,79 & 103 \\
\hline 97 & Macedonia & 12815 & 12117 & 133726 & 12137 & 10,44 & 121 \\
\hline 123 & Montenegro & 4717 & 4474 & 32182 & 5984 & 6,82 & 64 \\
\hline
\end{tabular}

Figure 5. Analysis of the number of articles, citations, $H$ index according to SJR: Scimago report for period 1996-2019.

However, when the analysis of the number of documents and citations per capita is made (Figure 6), Bosnia and Herzegovina is in last place among the successor countries of the former Yugoslavia, both in terms of the number of documents and the number of citations. The data presented in Figures 5 and 6 clearly indicate that in the post-war period Bosnia and Herzegovina lagged behind the most in important parameters that present the state of science in a particular country or community. 
Enver Zerem, Suad Kunosić: Influence of development of scientometrics on the outlook and functioning of the...

\begin{tabular}{ll}
\hline \multicolumn{2}{c}{ Number of Articles per population } \\
\hline Slovenia & 0,049 \\
\hline Croatia & 0,026 \\
\hline Serbia & 0,014 \\
\hline Montenegro & 0,008 \\
\hline Macedonia & 0,006 \\
\hline Bosnia and Herzegovina & 0,004 \\
\hline
\end{tabular}

\begin{tabular}{ll}
\hline \multicolumn{2}{c}{ Number of quotations per population } \\
\hline Slovenia & 0,713 \\
\hline Croatia & 0,268 \\
\hline Serbia & 0,141 \\
\hline Montenegro & 0,064 \\
\hline Macedonia & 0,052 \\
\hline Bosnia and Herzegovina & 0,027 \\
\hline
\end{tabular}

Figure 6. Number of articles and citations per capita, according to the SJR: Scimago report for period 1996-2019.

Why have we failed to control this sudden increase in the number of faculties, universities and scientists, and to harmonize it with the realistically expected scientific production that was supposed to follow it and be its necessary corrective factor?

Objective causes should be mentioned first. All university centres in Bosnia and Herzegovina, at the very beginning of the war (but also during the whole war and later), were left without a significant number of staff, who until that moment were the bearers of activities at those universities. It was necessary to replace those staff with other teachers in order to maintain the functioning of the university in wartime conditions. It is normal and expected that these replacements in wartime conditions, very often, were not adequate. However, after that, a decisive mistake was made. The academic community had failed to oppose propaganda and the creation of the general climate that dictated abandonment of the established and universal international scientific criteria in the academic community in favour of introducing local criteria that are only appropriate for a country in wartime. With the introduction of local criteria, the war-isolated academic community became a target of local politics, which began with the increasingly frequent 'insertion' of its own staff who, according to the new criteria, fully met the conditions. This led to the weakening of the influence of science, as the basic driving force of academia, and the strengthening of the influence of politics in our higher education institutions.

A part of the answer is contained in the Dayton setting of the position of education, including higher education in our country, where the work and even the establishment of new higher education institutions are decided on by entity, and in the Federation even by cantonal political structures. These structures have shown complete incompetence to decide on such sophisticated 
problems, without understanding the essence of the functioning of higher education. This also applies to areas such as Sarajevo, Banja Luka, Tuzla and Mostar, which were university centres even before the war. On the other hand, the small cantons, which had previously barely maintained the secondary education system, were given the right to establish universities and became real "El Dorados" for private colleges of uncontrolled and dubious quality and for local strongmen eager for university fame. Some cantons opened several private colleges and even universities, before even passing the Higher Education Act. Therefore, those institutions practically worked at their own discretion, void of any legal or even essential control regulations. ${ }^{15}$ All of the above has led to a real flood of scientific titles and teaching titles that are in no way correlated to real scientific production ${ }^{16}$. In this way, students get the wrong message at the beginning, so they do not identify with teachers who have achieved scientific achievements, but focus on obtaining scientific titles without science and on the fastest possible career advancement without objective indicators of scientific excellence. The question is whether it is now even worth introducing some standards in higher education at all, because we have already fabricated staff according to the current criteria who will be active at least until $2040 .{ }^{17}$

\section{Perspectives and Final Considerations}

The social significance and quality of scientific research largely depend on the usefulness of research results for the social and scientific community. The lack of funds for scientific research and the desire to allocate funding to highquality research projects make the assessment of the quality of research and the valorization of knowledge increasingly important.

However, in science and education there has always been an open question: which criteria can objectively assess the quality of work of higher education institutions and thus ensure the fulfilment of standards that provide adequate quality of resulting competencies. Since scientific research through innovations, patents and publications can be much more accurately measured and evaluated, compared to educational and other activities of universities, these parameters often appear as predetermining measures in evaluating the quality of higher education.

\footnotetext{
${ }^{15}$ Zerem, 2014:248-51

${ }^{16}$ Zerem, E., Kunosić, S., Imširović, B., \& Kurtčehajić, A. 136-142.

${ }^{17}$ Zerem, 2013;38:128; Zerem, 2014:248-51.
} 
In the current situation, when in no segment of our higher education there is a sufficient level of knowledge, commitment and determination to take systemic measures to improve the quality of our higher education institutions, it is difficult to say what measures should be taken to improve this situation so that our universities would advance on the ranking lists. It is clear that numerous shortcomings can be found in the criteria for forming university ranking lists, but the ranking systems, whether we like it or not, are becoming part of the reality of the existence and work of thousands of universities in the world.

The fact is that investments in scientific research work affect the improvement of scientific production. However, without the introduction of internationally recognized scientific criteria in the evaluation of scientific research, and the coordination of academic progress in accordance with the criteria, even the current miserable investment in science is essentially a useless waste of taxpayers' money. The second, no less important reason for such state of our higher education and science, is its fragmentation and the lowering of competencies over them to the entities and cantons, which are completely incompetent for that role. The existence of an effective regulatory institution at the level of Bosnia and Herzegovina, which would establish unique criteria in higher education at the state level with the possession of competencies and mechanisms for effective supervision of their implementation, would contribute to improving the situation in science and higher education.

\section{References}

1. Ashby, N. (2003). Relativity in the Global Positioning System. Living Rev Relativ. Vol. 6(1):1. DOI: 10.12942/1rr-2003-1

2. Bowen, A., Casadevall A. (2015). Increasing disparities between resource inputs and outcomes, as measured by certain health deliverables, in biomedical research. Proc Natl Acad Sci U S A. 112(36):11335-40. DOI: 10.1073/pnas.1504955112.

3. Brennan-Krohn, Z. The Bologna Process in Bosnia-Herzegovina: Strengthening, ReBranding, or Undermining Higher Education? In: 1st International Conference on Foreign Language Teaching and Applied Linguistics (FLTAL), Sarajevo/Bosnia and Herzegovina, 5-7 May 2011.

4. Dixon, A.K. (2009) Publishing and academic promotion. Singapore Med J. 50(9):847-50.

5. Hall, T. (1998) The haunted forest: a ghost story. Lancet 352:1230. DOI: 10.1016/S01406736(05)60578-8.

6. Horton, R. Publication and promotion. A fair reward. Lancet. 352:892. DOI: 10.1016/ S0140-6736(05)60578-8

7. Hounsfield, G.N. (1973) Computerized transverse axial scanning (tomography). 1. Description of system. Br J Radiol 46:1016-22. DOI: 10.1259/0007-1285-46-552-1016 
8. Kendrew, J.C., Perutz, M.F. (1948). A comparative X-ray study of foetal and adult sheep haemoglobins. Proc R Soc Lond A Math Phys Sci 194:375-98. DOI: 10.1098/ rspa.1948.0087.

9. Klaic, B. (1997). Analysis of scientific prodictivity in Croatia according to the Science Citation Index, Social Science Citation Index, and Arts \& Humanities Citation Index for the 1980-1995 period. Croat Med J. 38:88-98.

10. Kunosić, S., Čeke, D., Zerem, E.: Advantages and disadvantages of the webometrics ranking system. In: Kunosić, S., Zerem, E., (eds.) Scientometrics Recent Advances (2019). https://www.intechopen.com/books/scientometrics-recent-advances/advantagesand-disadvantages-of-the-webometrics-ranking-system

11. Čeke D and Kunosić S. (2021) Analiza kvalitete naučno-istraživačkog rada bazirana na citiranosti naučnih radnika i rangiranosti univerziteta u Covid-19 vremenu u Bosni i Hercegovini. Quality 2021 (S.Brdarević, S. Jašarević, editors)”, ISSN 1512-9268, Neum, B\&H, 17-19 June 2021., pp. 17-22

12. Marušić, A., Marušić M. (1999). Authorship criteria and academic reward. Lancet 353:1713-14.

13. Miles, K.A., Hayball, M., Dixon, A.K. Colour perfusion imaging: a new application of computed tomography. Lancet 1991; 337:643-5. DOI: 10.1016/0140-6736(91)92455-b.

14. Petković,B., Petković,D., Ćatić, R. (2013). Kako povezati sistem osiguranja kvaliteta u visokom obrazovanju sa aspekta postojećih sistema rangiranja univerziteta. Naučnostručni skup sa međunarodnim učešćem "QUALITY 2013", Neum, B\&H, 06. - 08. juni 2013. 154 Posebna izdanja ANUBiH CC, ODN knjiga 18, str. 135-154

15. Petković, B., Pehlić, I., Ćatić, R. Petković, D. Analiza spremnosti BH visokoškolskih organizacija za procese međunarodnih rangiranja rangiranja. Naučno-stručni skup sa sa međunarodnim učešćem "QUALITY 2015”, Neum, B\&H, 10. - 13. juni 2015.

16. Zerem, E. (2013). Right criteria for academia in Bosnia and Herzegovina. Lancet. 382:128. DOI: 10.1016/S0140-6736(13)61565-2

17. Zerem, E. (2014). Academic community in a developing country: Bosnian realities. Med Glas (Zenica). 11:248-51.

18. Zerem, E. (2017). The ranking of scientists based on scientific publications assessment. J Biomed Inform. 75:107-109. DOI: 10.1016/j.jbi.2017.10.007.

19.Zerem, E. (2018). The ranking of scientists. J Biomed Inform. 79:147-148. DOI: 10.1016/j.jbi.2018.02.007

20.Zerem, E.; Kunosić, S. (2018) The ranking of scientists: Computational calculation of Z-score. J. Biomed. Inform. 81: 133-134. DOI: 10.1016/j.jbi.2018.04.002.

21. Zerem, E., Kunosić, S., Imširović, B., \& Kurtčehajić, A. (2021). Science metrics systems and academic promotion: bosnian reality. Psychiatria Danubina, 33(suppl 3), 136-142. 